\title{
Neurophysiological assessment of the pelvic floor
}

The improbable marriage of neurophysiology to proctology has proved highly profitable in that the two disciplines have combined to study clinical areas in common, to the mutual benefit of each. The starting point has been anorectal incontinence, but later the emphasis has been extended to include other functional disorders such as constipation.

Gowers could be described as the first physiologist to display scientific interest in anal canal function and was the first to describe the rectoanal inhibitory reflex. ${ }^{1}$ Reflex responses affecting the internal anal sphincter were later studied in more detail by Denny Brown and Robertson ${ }^{2}$ and the first studies of external anal sphincter function were by Beck ${ }^{3}$ and Floyd and Walls. ${ }^{4}$ Interest in the anal sphincter by non-clinicians virtually ceases at this point. Clinical contributions to anal sphincter function were made by Kerremans, ${ }^{5}$ Schuster,${ }^{6}$ Frencker and Euler ${ }^{7}$ who largely used manometric techniques. Such methods are relatively crude and are largely restricted to determining smooth muscle activity, that is to say internal anal sphincter function. Investigation of the striated component using conventional electromyographic techniques, showed that these muscles are tonically active at rest and during sleep ${ }^{4}$ and contraction is reflexly evoked by coughing, sneezing or lifting heavy weights. ${ }^{8}$ Such activity is facilitated by means of a spinal reflex $\operatorname{arc}^{9}$ and as such is maintained in paraplegics if the level of cord section is above S2. Porter ${ }^{10}$ was able to show that in patients with rectal prolapse the conventional EMG was abnormal, in that action potentials were of low voltage and there was a poor interference pattern during periods of attempted voluntary contraction.

The interpretation of these observations was possible thanks to the combination of a proctologist, a neurophysiologist, and a neuropathologist who showed evidence of denervation in the pelvic floor muscle biopsies of patients with faecal incontinence and rectal prolapse using elegant enzyme histochemistry." The technique required visual assessment of the muscle under the microscope, however, and was open to observer error. An objective assessment of the innervation of the pelvic floor was then approached by studying the latency of the anal reflex in response to electrical stimulation of the perianal skin. ${ }^{12}$ This method often produced paradoxical results, however, because of the suprasegmental nature of the reflex. A much more satisfactory approach to objective investigation of somatic muscle function has been by single fibre EMG. ${ }^{13}$ The technique can be adapted to the study of pelvic floor musculature and has unequivocably shown that many patients with faecal incontinence have denervation damage to these muscles. ${ }^{14}$

Having established the presence of denervation, the next step was to 
identify the anatomical site of the neurological damage. Because the efferent pathway can be considered to comprise a central component (within the spinal cord) and a peripheral component (the pudendal nerves) methods to test each were required. The former was achieved by transcutaneous stimulation of the lumbar spine using a method devised by Merton. ${ }^{15} \mathrm{~A}$ single impulse of 800 to 1500 volts decaying with a time constant of 50 microseconds is delivered through two $1 \mathrm{~cm}$ in diameter saline soaked gauze pads placed over the spinous process of $\mathrm{L} 1$ and then repeated at the L4 position. In patients with peripheral nerve damage both latencies are increased more or less to an equal degree and the ratio of L1: latency L4 remains a constant. In patients with cauda equina disease however, the latency when the cord is stimulated at L1 is relatively longer than that at L4 and the ratio is increased. ${ }^{16}$ By using such nerve stimulation techniques it can be shown that most patients with faecal incontinence have denervation of the pelvic floor secondary to peripheral nerve damage: spinal cord disease occurring in only approximately $24 \%$ of patients. ${ }^{17}$

Sensory aspects of anorectal function have been previously explored using relatively crude methods. ${ }^{18}$ Roe $e t$ a $l^{19}$ have developed a device for testing anal sensation using a probe to which is delivered a current of constant value and which is not determined by the nature of tissue in contact with the electrode. Using this method Rogers et al describe, in this issue, a group of patients with faecal incontinence who have a sensory deficit in the anal canal which correlates closely with the motor deficit.

Have these techniques advanced our comprehension of anorectal continence? These are tests largely of the integrity of the motor unit supply to the pelvic floor and have not, in truth, advanced our understanding of the dynamics of anorectal function. The spinal stimulation latencies to the puborectalis and external anal sphincter muscles are dissimilar, so confirming initial theories that these muscles have separate innervations. ${ }^{20}$ The puborectalis is probably innervated on its pelvic surface by direct branches from the sacral plexus, while the external anal sphincter receives its supply from the pudendal nerves. In the research environment a neurophysiological approach has identified causative factors in many pelvic floor disorders. Denervation has not only been identified in rectal prolapse and faecal incontinence, but may also be a factor in constipation ${ }^{21}$ and solitary rectal ulcer syndrome..$^{22}$ The important roles played by childbirth and defecation straining in initiating the denervating process are now well established. ${ }^{23-25}$

Many proctologists will claim that sophisticated neurophysiological investigation of the pelvic floor offers as much information as can be gained by educated digital examination of the anal canal. In routine practice this is partly true. An assessment of pelvic floor function based on squeeze pressure is unreliable, however, as many normal patients experience considerable difficulty in complying with a request to contract maximally. In certain cases, spinal stimulation studies will reveal the small subgroup of patients with spinal disease who might require a neurosurgical referral in preference to pelvic floor surgery. It has to be stated, however, that the present development of methodology is far from complete. In patients with severe atrophy of the pelvic floor musculature there may be very limited electrical activity generated and single fibre estimations may be misleading. Nerve stimulation studies can be uncomfortable for the patient and accurate electrical localisation of the pudendal nerves is not always achieved. There is 
a continuing requirement then, to develop accurate techniques to quantify anorectal function. In the future, assessment of the total bulk of functioning sphincter muscle will almost certainly need the application of computer technology to neurophysiological techniques and it is hoped that the educated digital assessment of function will finally be rendered redundant.

Dept of Gastroenterology, Central Middlesex Hospital, London

\section{References}

1 Gowers WR. The automatic action of the sphincter ani. Proc R Soc (Lond) 1877; 26: 77-84.

2 Denny Brown D, Robertson EG. An investigation of the nervous control of defaecation. Brain 1935; 58: 256-310.

3 Beck A. Electromyographische Untersuchungen am sphinkter ani. Arch Physiol 1930; 224: 278-92.

4 Floyd WF, Walls EW. Electromyography of the sphincter ani extermus in man. J Physiol Lond 1953; 122: 599-609.

5 Kerremans R. Morphological and physiological aspects of anal continence and defaecation. Brussels: Editions Arscia, 1969.

6 Schuster MM, Hendrix TR, Mendeloff A. The internal anal sphincter response: manometric studies on its normal physiology, neural pathways and alteration in bowel diseases. $J$ Clin Invest 1963; 42: 196-207.

7 Frenckner B, Von Euler C. Influence of pudendal block on the function of the anal sphincters. Gut 1975; 16: 482-9.

8 Taverner D, Smiddy FG. An electromyographic study of the normal function of the external anal sphincter and pelvic diaphragm. Dis Colon Rectum 1959; 2: 153-60.

9 Parks AG, Porter NH, Melzack J. Experimental study of the reflex mechanism controlling the muscles of the pelvic floor. Dis Colon Rectum 1962; 5: 407-14.

10 Porter NH. Physiological study of the pelvic floor in rectal prolapse. Ann R Coll Surg Engl 1962; 31: 379-404.

11 Parks AG, Swash M, Urich H. Sphincter denervation in ano-rectal incontinence and rectal prolapse. Gut 1977; 18: 656-65.

12 Henry MM, Swash M. Assessment of pelvic floor disorders and incontinence by electrophysiological recording of the anal reflex. Lancet 1978; i: 1290-1.

13 Stalberg E, Thiele B. Motor unit fibre density in the extensor digitorum communis muscle. J Neurol Neurosurg Psychiatry 1975; 38: 874-80.

14 Neill ME, Swash M. Increased motor unit fibre density in the external sphincter in anorectal incontinence: a single fibre EMG study. J Neurol Neurosurg Psychiatry 1980; 43: 343-7.

15 Merton PA, Hill DK, Morton HB, Marsden CD. Scope of a technique for electrical stimulation of human brain, spinal cord and muscle. Lancet 1982; ii: 597-600.

16 Snooks SJ, Swash M. In: Henry MM, Swash M, eds. Nerve stimulation techniques in coloproctology and the pelvic floor. London: Butterworths, 1985: 112-4.

17 Snooks SJ, Swash M, Henry MM. Abnormalities in central and peripheral nerve conduction in patients with anorectal incontinence. $J$ R Soc Med 1985; 78: 294-300.

18 Duthie HL, Bennett RC. The relation of sensation in the anal canal to the functional anal sphincter: a possible factor in anal continence. Gut 1963; 4: 179-82.

19 Roe AM, Bartolo DCC, Mothensen NJ, Mc C. New method for assessment of anal sensation in various anorectal disorders. Br J Surg 1986; 73: 310-12.

20 Snooks SJ, Swash M. The innervation of the muscles of continence. Ann R Coll Surg Engl 1986; 68: 45-9.

21 Snooks SJ, Barnes PRH, Swash M, Henry MM. Damage to the innervation of the pelvic floor musculature in chronic constipation. Gastroenterology 1985; 89: 977-81.

22 Snooks SJ, Nicholls RJ, Henry MM, Swash M. Electrophysiological and manometric assessment of the pelvic floor in the solitary rectal ulcer syndrome. Br J Surg 1985; 72: $131-3$.

23 Henry MM, Parks AG, Swash M. The pelvic floor musculature in the descending perineum syndrome. Br J Surg 1982; 69: 470-2. 
24 Snooks SJ, Henry MM, Swash M, Setchell ME. Injury to innervation of pelvic floor sphincter musculature in childbirth. Lancet 1984; ii: 546-50.

25 Jones PN, Lubowski DZ, Henry MM, Swash M. Relation between perineal descent and pudendal nerve damage in idiopathic faecal incontinence. Int J Colorectal Dis 1987; 2: 93-5. 